\title{
PENGARUH PENGEMBANGAN KARIER TERHADAP RETENSI APARATUR SIPIL NEGARA (ASN) PADA SEKRETARIAT DAERAH KABUPATEN KERINCI
}

\author{
Ade Nurma Jaya Putra S.Sos., M.A.P \\ STIA Nusantara Sakti Sungai Penuh \\ Email: ade.nurmajaya@gmail.com
}

\begin{abstract}
ABSRACT
This study aims to determine the effect of career development on the Retention of the State Civil Apparatus (ASN) in the Kerinci Regency Regional Secretariat, while the population and sample in this study were 68 employees. The analytical tool used in this study is a simple linear regression by conducting a regression test, the results of this study indicate that Career Development has a significant influence on the Retention of State Civil Apparatus. This is evidenced by the results of t-test where tcount> ttable (17,992> 1,677), while the amount of Career Development that is proven by Rsquare is 0.831 or (83.1\%), while the remaining $16.9 \% \%$ is influenced by other variables
\end{abstract}

Keywords: Career Development, Retention

\begin{abstract}
ABSTRAK
Penelitian ini bertujuan untuk mengetahui pengaruh pengembangan karir terhadap Retensi Aparatur sipil Negara (ASN) pada Sekretariat Daerah Kabupaten Kerinci, adapun populasi dan sampel dalam penelitian ini adalah pegawai yang berjumlah 68 orang. Alat analisis yang digunakan dalam penelitian ini adalah regresi linear sederhana dengan melakukan uji regresi, hasil penelitian ini menunjukan bahwa Pengembangan Karir mempunyai pengaruh signifikan terhadap terhadap Retensi Aparatur Sipil Negara. Hal ini dibuktikan dengan hasil pengujian t-test dimana nilai $t_{\text {hitung }}>t_{\text {tabel }}(17.992>1,677)$, sedangkan besarnya pengaruh Pengembangan Karir yang dibuktikanya dengan Rsquare adalah sebesar 0.831 atau $(83,1 \%)$, sedangkan sisanya sebesar $16.9 \% \%$ dipengaruhi oleh variabel lain.
\end{abstract}

Kata Kunci : Pengembangan Karir, Retensi

\section{PENDAHULUAN}

\section{1 latar Belakang}

Perkembangan organisasi pada saat ini mengalami perubahan yang sangat cepat. Oleh sebab itu organisasi di tuntut harus memiliki strategi serta mampu melakukan pemberdayaan pegawainya untuk dapat bertahan dan bersaing dengan organisasi lainya, Sumber daya manusia memegang peranan yang sangat penting dan strategis untuk tercapainya tujuan organisasi, hal ini dikarenakan manusia merupakan perencana, pelaku, dan penentu terwujudnya tujuan organisasi tersebut meskipun sarana prasarana dan sumber daya lainnya mencukupi. Oleh sebab itu agar pelaksanaan tugas organisasi dapat berjalan efektif, efisien dan 
optimal dituntut pengembangan sumber daya manusia yang terencana dan berkelanjutan.

Kegagalan mengelola sumber daya manusia dapat mengakibatkan timbulnya gangguan dalam pencapaian tujuan organisasi, karena akan berhubungan langsung dengan kinerja, hal ini tentu cukup beralasan karena kinerja merupakan gambaran pencapaian pelaksanaan suatu kegiatan/ program/ kebijaksanaan dalam mewujudkan sasaran, tujuan, misi, dan visi organisasi Bastian (2014: 274). Salah satu yang dapat dilakukan untuk mempertahankan kinerja pegawai adalah mempertahankan pegawai yang berkompeten dan berpengalaman karerna dengan kehilangan pegawai yang berkompeten akan memperburuk keadaan serta menghambat pencapaian tujuan dalam organisasi itu sendiri maka dari itu perlunya ada retensi pegawai. menurut Jennifer (2005:2) menyatakan retensi karyawan adalah teknik yang digunakan manajemen untuk mempertahankan karyawan agar tetap dalam perusahaan selama jangka waktu tertentu. Jika pegawai tidak dapat menggunakan potensinya dengan penuh dan tidak didengar atau dihargai ditempat mereka bekerja, mereka akan pergi karena stres dan frustasi (Oladapo, 2014). Bagi organisasi mempertahankan orang - orang yang berkompeten sangat penting karena mempertahankan karyawan lebih baik daripada mencari karyawan baru (Jennifer, 2005:2)

Untuk mempertahankan retensi pegawai tentu tidak lah mudah karena dipengaruhi beberapa factor salah satunya adalah pengembangan karier pegawai itu sendiri, pengembangan karir merupakan aspek penting yang tidak boleh dilupakan dalam mengelola sumber daya manusia melalui adanya pengembangan karir akan dapat meningkatkan tingkat retensi karyawan. Pengembangan karir dapat dilakukan jika perusahaan dapat secara terbuka untuk memberikan kesempatan kepada karyawan untuk mengembangkan karirnya. Rivai (2011:274-279) menyatakan hal yang berkaitan dengan pengembangan karir seorang karyawan atau pegawai yaitu prestasi kerja (job performance), pengenalan(exposure), jaringan kerja (networking), pengunduran diri (resignations), kesetiaan terhadap organisasi (organizationalloyality), pembimbing dan sponsor (mentors and sponsors), bawahan yang mempunyai peranan kunci (key subordinates), peluang untuk tumbuh (growth opportunies), pengalaman (experience)

Sekretariat Daerah Kabupaten Kerinci sebagai suatu lembaga yang memiliki tugas membantu Bupati dalam melaksanakan tugasnya sebagai penyelenggaraan pemerintahan, baik itu dalam hal tugas administrasi, organisasi dan tata laksana serta memberikan pelayanan administrasif kepada seluruh perangkat daerah Kabupaten Kerinci lainnya, yang dibentuk berdasarkan Perda Kabupaten Kerinci Nomor 13 Tahun 2011, tentang Organisasi Sekretariat Daerah dan Sekretariat Dewan Perwaklilan Rakyat Daerah Kabupaten Kerinci Jo Peraturan Bupati Kerinci Nomor 10 Tahun 2011 tanggal 13 Juni 2011 tentang Uraian Tugas Pokok, Fungsi dan Tata Kerja Sekretariat Daerah Kabupaten Kerinci, Sekretariat Daerah Kabuapaten Kerinci, tentu membutuhkan sumber daya manusia yang 
berkualitas. Untuk mewujudkan visi Misi Sekretariat Daerah Kabupaten Kerinci pengembangan karir tentu menjadi salah satu aspek penting karena merupakan fakrot penting untuk meningkatkan retensi pegawai.

Berdasarkan Observasi awal yang peneliti laksanakan di sekretariat daerah Kabupaten Kerinci terkait dengan pengembangan karier pegawai terlihat masih rendah hal ini terlihat dari beberapa fenomena sebagai berikut

1. Masih banyak pegawai yang diangkat untuk meduduki jabatan tertentu belum sesuai dengan aturan.

2. Masih banyak pegawai yang mempunyai pengalaman kerja serta masa kerja yang lama belum menduduki jabatan yang sesuai.

3. Masih banyak pegawai yang belum diberdayakan sesuai dengan keahlianya.

4. hubungan antara atasan dan bawahan terkadang sering terjadi kecanggungan, serta dukungan untuk menapaki jenjang karir dalam organisasi masih kurang.

Berdasarkan fenomena yang penulis uraikan penulis tertarik untuk meneliti dengan judul Pengembangan karir terhadap retensi Aparatur Sipil Negara (ASN) pada Sekretariat Daerah Kabupaten Kerinci.

\subsection{Rumusan Masalah}

Berdasarkan latar belakang penelitian yang telah di kemukakan di atas, maka dapat di rumuskan dalam penelitian ini adalah sebagai berikut:

1. Apakah terdapat Pengaruh Pengembangan Karier terhadap Retensi Aparatur Sipil Negara pada Sekretariat Daerah Kabupaten Kerinci.?

2. Seberapa besar Pengaruh Pengembanagan Karir terhadap Retensi Aparatur Sipil Negara pada Sekretariat Daerah Kabupaten Kerinci.?

\subsection{Tujuan Penelitian}

Adapun tujuan dari penelitian ini adalah untuk mengetahui hal-hal sebagai berikut:

1. Untuk mengetahui pengaruh Pengembangan Karier terhadap Retensi Aparatur Sipil Negara pada Sekretariat Daerah Kabupaten Kerinci.

2. Untuk Mengetahui seberapa besar pengaruh Pengembangan Karier terhadap Retensi Aparatur Sipil Negara pada Sekretariat Daerah Kabupaten Kerinci.?

\subsection{Manfaat Penelitian}

Adapun manfaat penelitian yang ingin di capai dalam penelitian ini adalah Sebagai berikut :

\section{Manfaat Praktis}

Penelitian ini diharapkan menjadi sumbangan pemikiran bagi dinas/instansi dalam mengembangkan sumber daya manusia

2. Manfaat Akademis

Dengan penulisan Proposal ini diharapkan dapat memberikan manfaat bagi penulis dalam mengembangkan wawasan berfikir dan menambah pembendaharaan pengetahuan, khususnya mengenai konsep dan teori- teori yang berhubungan dengan penelitian ini. 


\subsection{Tinjauan Pustaka}

\section{Pengembangan Karir}

Menurut Dessler (2013:353), pengembangan karir merupakan seri sepanjang hidup kegiatan yang berkontribusi terhadap eksplorasi karir seseorang, pendirian, kesuksesan, dan kepuasan. Menurut Rivai (2009 : 274), pengembangan karir adalah proses peningkatan kemampuan kerja individu yang dicapai dalam rangka memcapai karir yang di inginkan.

Menurut Mondy (2010:228), pengembangan karir adalah pendekatan formal yang digunakan oleh perusahaan untuk memastikan bahwa orang-orang dengan kualifikasi dan pengalaman yang tepat, tersedia saat dibutuhkan. Dalam perikatan karyawan dengan perusahaan tempatnya bekerja perlu diciptakan harmoni hubungan di wilayah pengembangan karir yang akan menciptakan beneficial mutualis, yakni suatu kondisi dimana karyawan dan perusahaan sama-sama memetik manfaat dan terus dapat berkembangnya segenap potensi diri karyawan yang selaras dengan berkembangnya organisasi.

\section{Retensi}

Menurut Mathis dan Jackson (2006: 126), retensi merupakan upaya untuk mempertahankan agar tetap berada dalam organisasi guna mencapai tujuan organisasi tersebut.Kinerja perusahaan merupakan suatu tampilan secara utuh atas perusahaan selama periode tertentu, merupakan hasil atau prestasi yang di pengaruhi oleh kegiatan operasional perusahaan dalam memanfaatkan sumbersumber daya yang di miliki. Salah satu cara untuk mempertahankan bahkan meningkatkan kinerja perusahaan yaitu dengan menjaga retensi karyawan agar tetap tinggi. Sedangkan menurut Sumarni (2011), employee retention atau retensi karyawan merupakan kemampuan perusahaan untuk mempertahankan karyawan potensial yang dimiliki perusahaan untuk tetap loyal terhadap perusahaan.

Tujuan dari retensi karyawan ialah untuk mempertahankan karyawan yang dianggap berkualitas yang dimiliki perusahaan selama mungkin, karena karyawan yang berkualitas merupakan harta yang tidak tampak (intangible asset) yang tak ternilai bagi perusahaan. Dari pengertian-pengertian di atas, bahwa retensi karyawan adalah suatu proses dimana sebuah perusahaan mampu mempertahankan karyawannya yang potensial agar tetap loyal terhadap perusahaan dengan jangka waktu yang lebih lama.

\subsection{Kerangka Pemikiran}

Kerangka pemikiran ini dimaksudkan sebagai konsep untuk menjelaskan hubungan variabel yang akan diteliti berdasarkan perumusan masalah, adapun kerangka pemikiran dalam penelitian ini adalah terdiri dari variabel bebas satu (X) variabel terikat Satu (Y), Yaitu 


\section{Variabel $X$ (Pengembangan Karir)}

Menurut Rivai (2009 : 274), pengembangan karir adalah proses peningkatan kemampuan kerja individu yang dicapai dalam rangka mencapai karir yang di inginkan. Dengan Indikatornya antara lain:

1) Perlakuan yang adil dalam karir

Perlakukan yang adil itu hanya bisa terwujud apabila kriteria promosi didasarkan pada pertimbangan-pertimbangan yang objektif, rasional, dan diketahui secara luas dikalangan karyawan.

2) Kepedulian para atasan langsung Para karyawan pada umumnya mendambakan keterlibatan langsung mereka dalam perencanan karir masing-masing. Salah satu bentuk keperdulian itu adalah memberikan umpan balik kepada para karyawan tentang pelaksanaan tugas masingmasing karyawan tersebut mengetahui potensi yang perlu diatasi. Pada giliranya umpan balik itu merupakan bahan penting bagi karyawan mengenai langkah awal apa yang perlu diambilnya agar kemungkinannya untuk dipromosikan menjadi lebih besar.

3) Informasi tentang berbagai peluang promosi

Para karyawan pada umumnya mengharapkan bahwa mereka memiliki akses kepada informasi tentang berbagai peluang untuk dipromosikan. Akses ini sangat penting terutama apabila lowongan yang tersedia diisi melalui proses seleksi internal yang bersifat kompetitif. Jika akases demikian tidak ada atau sangat terbatas para karyawan akan mudah beranggapan bahwa prinsip keadilan dan kesamaan dan kesempatan untuk dipertimbangkan.

4) Adanya minat untuk dipromosikan

Pendekatan yang tepat digunakan dalam hal menumbuhkan minat para karyawan untuk pengembangan karir adalah pendekatan fleksibel dan proaktif. Artinya, minat untukmengembangan karir sangat individualistic sifatnya. Seorang karyawan memperhitungkan berbagai faktor seperti usia, jenis kelamin, jenis dan sifat pekerjaan sekarang, pendidikan dan pelatihan yang ditempuh, jumlah tanggungan dan berbagai faktor lainnya. Berbagai faktor tersebut dapat berakibat pada besarnya minat seseorang untuk mengembangkan karirnya.

\section{Variabel Y (Retensi)}

Menurut Mathis dan Jackson (2006: 126), retensi merupakan upaya untuk mempertahankan agar tetap berada dalam organisasi guna mencapai tujuan organisasi tersebut. Adapun indikator-indikator antara lain :

1) Organisasi dan manajemen

Beberapa komponen organisasi mempengaruhi karyawan dalam memutuskan apakah bertahan atau meninggalkan perusahaan mereka.Termasuk didalamnya budaya dan nilai yang positif dalam organisasi. Strategi, peluang, dan manajemen organisasional di dalam perusahaan yang dikelola dengan baik juga akan mempengaruhi retensi karyawan. 
2) Hubungan kerja

Dimana rekan kerja tidak pernah bertindak diskriminatif (membedabedakan) antara karyawan yang satu dengan yang lainnya.Hubungan kerja mempengaruhi retensi karyawan termasuk didalamnya memotivasi manajemen dan relasi rekan kerja.

3) Pekerjaan dan Kehidupan Kerja

Faktor mendasar yang mempengaruhi retensi karyawan adalah sifat dari tugas dan pekerjaan yang dilakukan.Dimana organisasi yang memiliki tingkat kelangsungan pekerjaan dan keamanan yang tinggi cenderung memiliki tingkat retensi yang lebih tinggi.

4) Penghargaan

Dimana perusahaan selalu memberikan penghargaan atas kinerja yang telah dilakukan oleh karyawan.Penghargaan dalam bentuk fisik misalnya (Gaji atau upah), insentif, dan keuntungan atau manfaat.

5) Kebijakan dan Praktik Kerja

Faktor yang ditemukan untuk mempengaruhi retensi didasarkan pada kebijakan dan hubungan kerja yang ada.Seperti kebijakan dan disiplin kerja

\section{Gambar 1.1 kerangka pemikiran}

\begin{tabular}{|l|l|}
\multicolumn{1}{|c|}{ Pengembangan Karir $(\mathrm{X})$} & \multicolumn{1}{c|}{ Retensi (Y) } \\
1. Perlakuan yang adil dalam karir & \multicolumn{1}{|c|}{ 1. Organisasi dan manajemen } \\
2. Kepedulian para atasan langsung & 2. Hubungan kerja \\
3. Informasi tentang berbagai peluang promos & 3. Pekerjaan dan Kehidupan Kerja \\
4. Adanya minat untuk dipromosikan & 4. Penghargaan \\
Sumber : Rivai (2009: 274) & 5. Kebijakan dan Praktik Kerja \\
& Sumber : Mathis dan Jackson \\
& $(2010: 165)$ \\
\hline
\end{tabular}

Skema di atas menggambarkan bahwa dalam penelitian ini akan dilihat adakah pengaruh Pengembangan Karir terhadap Retensi Aparatur Sipil Negara (ASN) pada pada Sekretariat Daerah Kabupaten Kerinci.

\subsection{Hipotesis}

Pengertian hipotesis menurut Sugiyono (2009: 64) adalah jawaban sementara terhadap rumusan penelitian di mana rumusan masalah penelitian telah dinyatakan dalam bentuk kalimat pernyataan. Dikatakan sementara, karena jawaban yang diberikan baru didasarkan pada teori yang relefan, belum didasarkan pada fakta-fakta empiris yang diperoleh melalui pengumpulan data. Jadi hipotesis juga dapat dinyatakan sebagai jawaban teoritis terhadap rumusan masalah penelitian, belum jawaban yang empirik.

Berdasarkan pengkajian dari uraian di atas sehingga hipotesis ini dapat dikemukakan sebagai berikut: 
H0 $: r=0$ Di duga tidak terdapat pengaruh yang signifikan antara Pengembangan Karier terhadap Retensi Aparatur Sipil Negara pada Sekretariat Daerah Kabupaten Kerinci.

Ha $: r \neq 0$ Di duga terdapat pengaruh yang signifikan antara Pengembangan Karier terhadap Retensi Aparatur Sipil Negara pada Sekretariat Daerah Kabupaten Kerinci

\section{METODE PENELITIAN}

\subsection{Metode Penelitian}

Adapun Metode Penelitian yang digunakan dalam penelitian ini adalah sebagai berikut

\subsubsection{Pendekatan Penelitian}

Pendekatan penelitian yang digunakan dalam penelitian ini adalah Kuantitatif. Sugiono (2011: 37) kuantitatif adalah data yang berwujud angkaangka yang diperoleh sebagai hasil pengukuran atau penjumlahan. Data-data kuantitatif inilah yang kemudian yang kemudian bisa diolah dengan tekhnik statistik. Teknik analisis yang digunakan untuk menganalisis dengan melakukan perhitungan pengaruh Pengembangan Karier terhadap Retensi Aparatur Sipil Negara pada Sekretariat Daerah Kabupaten Kerinci.

\subsubsection{Populasi}

Menurut Riduwan (2009: 6) populasi merupakan objek atau subjek yang berada pada suatu wilayah dan memenuhi syarat-syarat tertentu berkaitan dengan masalah penelitian. Sugiyono (2009: 80), populasi adalah wilayah generalisasi yang terdiri atas objek atau subjek yang mempunyai kualitas dan karakteristik tertentu yang ditetapkan oleh peneliti untuk dipelajari dan kemudian ditarik kesimpulannya. Berdasarkan kualitas dan ciri tersebut, populasi dapat dipahami sebagai sekelompok individu atau objek pengamatan yang minimal memiliki satu persamaan karakteristik.

Populasi dalam penelitian ini adalah seluruh Aparatur Sipil Negara (ASN) pada Sekretariat Daerah Kabupaten Kerinci yang berjumlah 123 orang.

\subsubsection{Sampel}

Untuk memperoleh sampel pada penelitian ini, peneliti menggunakan rumus Slovin (Husein Umar, 2014:78), yaitu sebagai berikut:

$$
\mathrm{n}=\frac{N}{1+N\left(e^{2}\right)}
$$

Keterangan:

$\mathrm{n} \quad=$ Jumlah sampel

$\mathrm{N} \quad=$ Jumlah populasi

e =presentase kelonggaran karena kesalahan pengambilan sampel yang masih ditolelir (ketidaktelitian).

Dalam penelitian ini $\mathrm{N}=123$ dan $\mathrm{e}=0,08$, maka: 


$$
\begin{aligned}
& \mathrm{n}=\frac{123}{1+123(0.08)^{2}} \\
& \mathrm{n}=\frac{123}{1+0,7872} \\
& \mathrm{n}=\frac{123}{1,7872} \\
& \mathrm{n}=68,22 \rightarrow 68
\end{aligned}
$$

Berdasarkan hitungan di atas didapatkan jumlah sampel sebesar 68 dari 123 jumlah pegawai Sekretariat Daerah Kabupaten Kerinci. Untuk penentuan sampel dalam penelitian ini menggunakan teknik propotional stratified random sampling yaitu teknik pengambilan sampel yang diambil dari masing-masing sub populasi yang diambil secara acak berdasarkan proporsi jumlah pangkat golongan pegawai yang ada pada setiap subpopulasi.

Table Distribusi Sampel Penelitian

\begin{tabular}{|c|c|c|c|c|}
\hline Pangkat & $\begin{array}{c}\text { Jumlah } \\
\text { Populasi }\end{array}$ & \multicolumn{2}{|c|}{ Proporsi Sampel } & Jumlah Sampel \\
\hline Golongan IV & 30 & $30 / 123 \times 68=$ & 16,58 & 16 \\
\hline Golongan III & 61 & $61 / 123 \times 68=$ & 33,72 & 33 \\
\hline Golongan II & 32 & $32 / 123 \times 68=$ & 17,69 & 17 \\
\hline Jumlah & $\mathbf{1 2 3}$ & $\mathbf{1 2 3}$ & $\mathbf{6 7 . 9 9}$ & $\mathbf{6 8}$ \\
\hline
\end{tabular}

\subsubsection{Teknik Pengumpulan Data}

Teknik pengumpulan data adalah cara-cara yang digunakan untuk mengumpulkan data dan keterangan-keterangan lainnya dalam penelitian yang dilakukan. Teknik pengumpulan data primer yang digunakan adalah field research, yang dilakukan dengan cara:

1. Observasi

Observasi merupakan cara atau teknik untuk memperoleh data dengan mengadakan pengamatan langsung dilokasi penelitian.

2. Kuesioner

Kuesioner adalah teknik pengumpulan data dengan menyebarkan suatu daftar pertanyaan yang diajukan secara tertulis kepada responden, dalam penelitian ini penulis, menyebarkan kuesioner pada masyarakat pengguna jasa pelayanan pada Kantor Pertanahan Kabupaten Kerinci.

\subsubsection{Interprestasi data}

\section{Skala Likert}

Sugiono (2009: 93) Skala likert digunakan untuk mengukur sikap, pendapat, dan persepsi seseorang atau sekelompok orang tentang fenomena sosial. Dalam penelitian, fenomena sosial ini telah ditetapkan secara spesifik oleh peneliti, yang selanjutnya disebut sebagai variabel penelitian.

Setiap jawaban dari responden diklasifikasikan sebagai berikut:
SS = Sangat Setuju
diberi skor 5
ST = Setuju
KS = Kurang Setuju
diberi skor 4
TS = Tidak Setuju
diberi Skor 3
diberi skor 2 
STS = Sangat Tidak Setuju diberi skor 1

Sumber: Imam Ghozali (2013:47)

\section{Analisis Regresi Linear Sederhana}

Analisis Regresi Sederhana adalah suatu alat analisis peramalan nilai pengaruh satu variabel bebas terhadap variabel terikat untuk membuktikan ada atau tidaknya hubungan fungsi atau hubungan kausal antara variabel bebas dengan variabel terikat (Riduwan, 2005 : 155). Menurut Ghozali (2006:82) dalam analisis regresi selain mengukur kekuatan hubungan antara dua variabel dependen dengan variabel independen. Artinya model regresi dapat digunakan untuk menentukan variabel yang mempengaruhi dan variabel yang dipengaruhi. Sesuai dengan desain penelitian ini, dengan instrument angket skala likert maka data penelitian yang dikumpulkan berskala interval, maka untuk model penelitian ini teknik analisis yang layak digunakan adalah teknik regresi, khususnya regresi sederhana.

Persamaan regresi sederhana dirumuskan sebagai berikut :

$\boldsymbol{Y}=\boldsymbol{a}+\boldsymbol{b} \boldsymbol{X}$

Keterangan :

$\mathrm{Y}=$ Retensi (Variabel terikat)

a = nilai konstanta

$\mathrm{b} \quad=$ koofisien regresi

$\mathrm{X}=$ Pengembangan Karier (Variabel bebas)

Untuk mempermudah peneliti, data di olah dengan bantuan Program SPSS

Versi 17.0 For Windows

\section{Koofesien determinasi}

Koefisien determinasi merupakan kuadrat dari koefisien korelasi. Analisis ini digunakan untuk mengetahui seberapa besar pengaruh variabel independen $(\mathrm{X})$ terhadap variabel dependen $(\mathrm{Y})$.

$K D=r_{x y^{2}} x 100 \%$

Dimana:

$\mathrm{KD}=$ Koefisien Determinasi

$\mathrm{r}_{x y}{ }^{2}=$ Koefisien kuadrat korelasi ganda

Untuk mempermudah peneliti, data di olah dengan bantuan Program SPSS

Versi 17.0 For Windows.

\section{Uji t}

Uji $\mathrm{t}$ adalah bagian dari uji statistik yang merupakan yang digunakan untuk membuktikan pengaruh variabel $\mathrm{X}$ terhadap variabel Y, maka dihitung dengan rumus Sugiono (2009: 184) sebagai Berikut:

$$
t=\frac{r \sqrt{n-2}}{\sqrt{1-r^{2}}}
$$

Dimana:

$$
\begin{array}{ll}
\mathrm{t}_{\text {hitung }} & =\text { Nilai } \\
\mathrm{r} & =\text { Nilai Koefisien Korelasi }
\end{array}
$$




\section{HASIL DAN PEMBAHASAN}

\section{Analisis Regresi Linear Sederhana}

Pada penelitian ini teknik analisis data yang digunakan adalah regresi linear Sederhana. Teknik analisis ini digunakan untuk mengetahui besarnya pengaruh pengembangan karir terhadap Retensi Aparatur Sipil Negara (ASN) pada Sekretariat Daerah Kabupaten Kerinci, dengan pengolahan SPSS versi 16.0 maka didapat hasil regresi sebagai berikut:

Tabel 3.1

Hasil Analisis Regresi

Coefficients $^{\mathrm{a}}$

\begin{tabular}{|c|c|c|c|c|c|}
\hline \multirow[b]{2}{*}{ Model } & \multicolumn{2}{|c|}{ Unstandardized Coefficients } & $\begin{array}{c}\text { Standardized } \\
\text { Coefficients }\end{array}$ & & \\
\hline & $B$ & Std. Error & Beta & $\mathrm{t}$ & Sig. \\
\hline $1 \quad$ (Constant) & 7.663 & 2.101 & & 3.648 & .001 \\
\hline $\begin{array}{l}\text { PENGEMBANGAN } \\
\text { KARIR }\end{array}$ & .952 & .053 & .911 & 17.992 & .00 \\
\hline
\end{tabular}

a. Dependent Variable: RETENSI

Dalam penelitian ini, hasil regresi Linear Sederhana menggunakan standardized coefficients. Persamaan linier dari hasil regresi yang didapat adalah sebagai berikut :

$\mathrm{Y}=7.663+0.952$

Keterangan :

1. Nilai $\alpha($ Constan $)=7.663$

Artinya apabila dianggap tidak ada Pengembangan Karir (=0) maka Retensi sebesar 7.663

2. Nilai $b=0.952$

Artinya terjadi peningkatan apabila pengembangan Karir dinaikan 1satuan maka Retensi Aparatur Sipil Negara (ASN) akan mengalami peningkatan sebesar 0.952 atau $(95.2 \%)$

\section{Koifesien Determinasi $\left(\mathbf{R}^{2}\right)$}

Koifesien determinasi $\left(\mathrm{R}^{2}\right)$ pada intinya mengukur seberapa jauh kamampuan model menerangkan variasi variabel dependennya. Nilai koefisen determinasi yang mendekati satu berarti variabel -variabel independenya menjelaskan hampir semua informasi yang dibutuhkan untuk mempredeksi variabel dependen (Ghozali.2009). hasil perhitungan determinasi penelitian ini dapat dilihat pada tabel berikut :

Tabel 3.2

\section{Koifesien Determinasi}

\section{Model Summary}

\begin{tabular}{|l|l|l|l|l|}
\hline Model & R & R Square & Adjusted R Square & Std. Error of the Estimate \\
\hline
\end{tabular}




\begin{tabular}{|l|r|r|r|}
\hline 1 & $.911^{\mathrm{a}}$ & .831 & .828 \\
\hline
\end{tabular}

a. Predictors: (Constant), PENGEMBANGAN KARIR

Nilai $\mathrm{R}^{2} \quad(r$ square) sebesar 0.831 atau $(83,1 \%)$ yang artinya variabel Pengembangan Karir mampu mempengaruhi Retensi Aparatur Sipil Negara (ASN) pada Sekretariat Daerah Kabupaten Kerinci sebesar 83,1\% sementara sisanya sebesar $16,9 \%$ di pengaruhi faktor variabel lain

\section{Uji -t ( Uji Partial)}

Uji-t ini digunakan untuk membuktikan adanya pengaruh yang signifikan antara Pengembangan Karir terhadap Retensi Aparatur Sipil Negara (ASN) pada Sekretariat Daerah Kabupaten Kerinci secara partial. Ketentuan t tabel (Sugioyono $2007: 368)$ :

$\alpha=0,05$ (satu sisi) ; $\mathrm{n}-2=68-2=66$, maka $\mathrm{t}$ tabel $=1.668$ Ketentuan penerimaan hipotesis yaitu :

Ha ditolak bila sig. $>0,05$ atau $t$ hitung $<\mathrm{t}$ tabel

Ha diterima bila sig. $\leq 0,05$ atau $t$ hitung $>$ t tabel

Berdasarkan hasil pengolahan dengan program SPSS Versi 16.00 maka di dapat hasil uji - t, yang hasilnya dirangkum pada tabel berikut ini :

\section{Tabel 3.3}

\section{Hasil Uji - t}

Coefficients $^{a}$

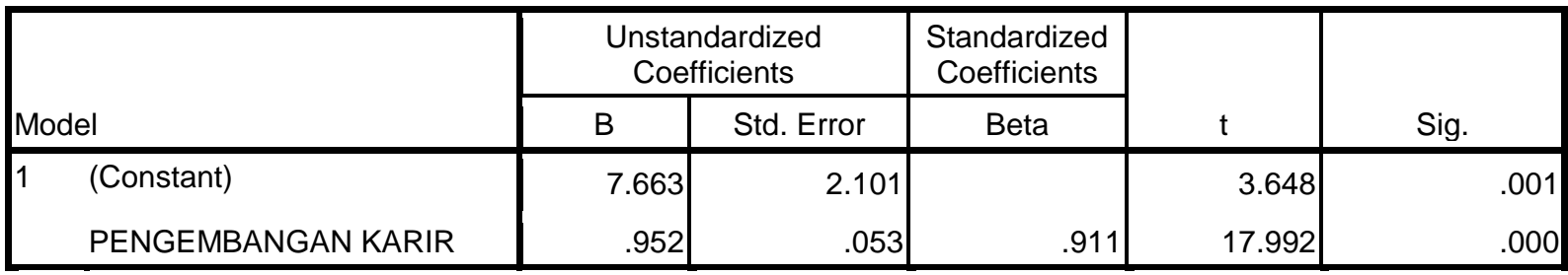

a. Dependent Variable: RETENSI

Berdasarkan hasil pengolahan data pada tabel diatas diketahui $\mathrm{T}_{\text {hitung }} 17.992$ dengan nilai signifikansi $0,000<0,05$. Merujuk pada perhitungan diatas maka dapat diputuskan sebagai berikut : dimana $\mathrm{T}_{\text {hitung }}>\mathrm{T}_{\text {tabel }}$ atau 17.992>1,677 maka Ho ditolak dan Ha diterima, yang berarti Ada pengaruh yang nyata (signifikan) antara variabel Pengembangan Karir (X) terhadap variabel Retensi (Y). Dengan demikian dapat disimpulkan bahwa terdapat pengaruh yang signifikan antara pengembangan karir terhadap Retensi Aparatur Sipil Negara (ASN) pada Sekretariat Daerah Kabupaten Kerinci.

\section{IV.SIMPULAN}

Berdasarkan hasil pengolahan data pada bab sebelumnya dengan menggunakan program SPSS 17.00 untuk menganalisis pengaruh Pengembangan Karir terhadap Retensi Aparatur Sipil Negara (ASN) pada Sekretariat Daerah Kabupaten Kerinci, dengan hasil sebagai berikut: 
1. Diketahui Persamaan regresi $Y=7.663+0.952$ yang mengandung arti jika tidak ada kenaikan nilai variabel Pengembangan Karir (X) maka Retensi (Y) Aparatur Sipil Negara (ASN) Sebesar 7.663 dan apabila Pengembangan Karir dinaikan sebesar 1 satuan maka Retensi Aparatur Sipil Negara (ASN) akan mengalami peningkatan sebesar 0.952 atau $(95,2 \%)$.

2. Untuk mengetahui sebesar apakah Pengembangan Karir mempengaruhi Retensi dapat dilihat pada hasil koifisien determinasi $\left(\mathrm{R}^{2}\right)$. Dari olah data diperoleh determinasi sebesar 0.831 atau $(83,1 \%)$. Ini Pengembangan Karir berpengaruh terhadap Retensi sebesar $83,1 \%$

3. Untuk melihat tingkat signifikan atau tidaknya berpengaruh variable independen terhadap variable dependen dilakukan uji t. beradasarkan uji t, dari hasil regresi nilai thitung Pengembangan Karir adalah 17.992 jika dibandikan dengan signifikan yang telah ditentukan yaitu $\alpha=0,05$ ( tabel $=1,677)$ maka $t_{\text {hitung }}>t_{\text {tabel }}(17.992>1,677)$, dengan demikian Ha diterima dalam arti kata Pengembangan Karir berpengaruh signifikan terhadap Retensi pegawai.

\section{UCAPAN TERIMA KASIH}

Terima Kasih Kepada LPPM STIA Nusantara sakti Sungai Penuh yang telah memberi kesempatan untuk publish jurnal OJS Jurnal Administrasi Nusantara (JAN), serta semua pihak yang tidak bisa disebutkan satu persatu dalam jurnal ini.

\section{DAFTAR PUSTAKA}

Bastian Indra, 2014. Audit Sektor Publik: Pemeriksaan Pertanggungjawaban Pemerintahan. Edisi ke-3. Jakarta: Salemba empat

Jennifer A, Carsen. 2005. HR How To Employee Retention. Chicago : J.D. CCH Incorporated. 2(2), pp: 162-165

Fitz-enz, J. (1990). Getting and keeping good employees. In personnel. 67(8), pp: $25-29$

Ghozali, Imam. 2011. Aplikasi Analisis Multivariate dengan Progam SPSS. Semarang: Badan Penerbit Universitas Diponegoro.

Mathis, Robert L. \& John H. Jackson, 2010. Human Resource Management 10th Edition, Penterjemah Dian Angelica, Salemba Empat, Jakarta

Mondy, R. Wayne, Noe Robert M., 2010. Human Resource Management, Tenth Edition, Jilid I, Penterjemah Bayu Airlangga, M.M., Penerbit Erlangga, Jakarta.

2013. Aplikasi Analisis Multivariate dengan Progam SPSS Semarang: Badan Penerbit Universitas Diponegoro

Rivai. V \& Sagala. E.J. 2009. Manajemen Sumber Daya Manusia untuk Perusahaan : Dari Teori ke Praktik edisi kedua. Jakarta: Rajawali Pers 
. 2011. Manajemen Sumber Daya Manusia Untuk Perusahaan. Jakarta: PT. Raja Grafindo Persada.

Riduwan. 2003. Dasar-dasar Statistika. Bandung: Alfabeta

Sugiyono, 2009, Metode Penelitian Pendidikan (Pendekatan Kuantitatif, Kualitatif dan $R \&$, Alfabeta :Bandung.

Sugiono.2011. Metode Penelitian Pendidikan Pendekatan Kuantitatif, Kualitatif,dan $R \& D$. Bandung: Alfabeta

Oladopo, Victor. 2014. The Impact Of Talent Management On Retention. Journal of Business Studies Quarterly. 5(3), pp: 20-36. 